\title{
MEANING-CENTERED MANAGEMENT OF THE VIRTUAL EDUCATIONAL ENVIRONMENT IN THE ACADEMIC TRAINING OF PEDAGOGICAL SPECIALISTS
}

\author{
Sofia Dermendjieva ${ }^{1}$ \\ South-West University "Neofit Rilski" - Blagoevgrad, Bulgaria \\ Lazar Stošić \\ Institute of management and knowledge, Regional coordinator for Republic of \\ Serbia, Senior Researcher, Skopje, Macedonia \\ Gergana Dyankova \\ South-West University "Neofit Rilski” - Blagoevgrad, Bulgaria
}

\begin{abstract}
As the last institution at the end of the education system, the university is committed to preparing competent professionals for each field of expertise, including future teachers. An essential goal in the training of pedagogical specialists is to get to know the potential of the personality and to enhance its development at all key levels. The situation with Covid-19 has highlighted its growing importance, given the urgent need to transition from face-to-face learning to distance education. In the course of the rapidly spreading epidemic, the role of ICT in education became clear. It has been proven that in the conditions of global crisis it is the information and communication technologies that successfully mediate the learning process. It was found that digital competencies are vital for the subjects in the pedagogical interaction, because they ensure the dialogue in the virtual educational environment. Undoubtedly, the foundation of its qualitative implementation affects the motivation for selfactualization of interacting between teachers and students. After identifying the need to improve the quality of distance education, this article presents the advantages of meaning-centered management of virtual educational environments in the academic preparation of pedagogical specialists. The following questions become relevant: (1) What is the meaning?; (2) What will develop?; (3) How will it be formed?, which respectively constitute the conceptual, personal and activity aspect of the pedagogical interaction from a distance.
\end{abstract}

Keywords: higher pedagogic education, meaning-centered management in virtual environment, quality of distance education, professional pedagogical competence.

\footnotetext{
${ }^{1}$ sofger@swu.bg
} 


\section{Introduction}

In previous years, higher education institutions for pedagogical specialist training were required to use their potential in the best way to accelerate modernization and internationalization at all levels of the education system. Recently, the education system is striving to be in unison with the challenges of the modern age. Modernization in education is aimed at:

- $\quad$ on the one hand - improving the learning environment in the educational institutions through enhanced implementation of information and communication technologies;

- $\quad$ on the other hand - achieving (1) functional and (2) multi-dimensional literacy of learners, defined as:

(1) ability to use knowledge and skills from key cognitive domains to solve problematic situations;

(2) an ability that is the basis for participation in the digital society and making informed choices on issues in a high-tech environment (Dermendjieva and Dyankova, 2018).

Ensuring conditions for quality education is directly related to the application of the competence approach, which:

- $\quad$ emphasizes the end results of training and the acquisition of knowledge and skills that are reciprocal in the content of the relevant educational level and are of high relevance in real life, in other words personally oriented towards the needs of the trainees;

- has a two-way meaning and scope, since it refers both to the teacher/trainer as a professional subject and to the child/student as an active subject of the educational activity.

A more significant feature of the competence approach display is the systematic comprehension and upgrading of intellectual, communicative, reflexive and moral norms that allow the individual to direct his activity in a broad social, economic and cultural sense.

\section{Pandemic Covid-19 and the challenges prior to the academic preparation of pedagogical specialists for virtual education environments}

Unfavorable events connected to the spread of Covid-19 imposed enormous lifestyle changes. The introduction of quarantine due to the Pandemic and the measures for social distancing changed radically the functioning of educational institutions. The higher education institutions also reorganised their working habits with students and made transition from attending in-class sessions to remote learning. At the same time, social media intensified the question about the quality of online education. It became clear that there were two opinions about online education: 
there are the people who favor online education and the people that disprove its advantages and efficiency.

An objective analysis requires the acknowledgment of the efforts of the academic community for handling the crisis. It's also important to take a look at the challenges that they overcame.

\section{Emerging needs prior to the academical preparations of pedagogical specialists in virtual educational environments}

Modern studies show that traditional educational activities at the university level do not play an important role in the globalizing world.

The waning interest in the academic career is related to the lack of opportunities for systematic professional qualification and for the enhancement of pedagogical competence. Additionally, this has a negative impact on the quality of teaching at the university level and implies that the need for permanent updating is imperative.

Reflected in the context of higher education, the competence approach addresses the conflicting contradiction between institutional models of professional behavior by university lecturers and the need for adequate pedagogical reflection on effective academic interaction. This growing tendency of "blurring the boundaries" between professional training, long-time student experience and dynamically changing educational needs reflects the difficulties faced by a modern university lecturer in the context of pedagogical practice as an organizational and professional situation.

What is new in the situation is that the teacher has to improve his / her professional pedagogical competences simultaneously with the students and in this sense no particular distance is registered in his / her position both as a trainer and a trainee.

At the same time, dynamic and effective interaction in both face-to-face teaching and in online mode are demanded from the trainer.

This growing tendency of "blurring the boundaries" between professional training, long-time student experience and dynamically changing educational needs reflects the difficulties faced by a modern university lecturer in the context of pedagogical practice as an organizational and professional situation.

Moreover, in the context of online education:

- on an individual level - conscious or unconscious - the outlined trend reflects what depleted the professional motivation of teachers, expressed in formalizing, distancing, dehumanizing and neglecting the essential function of the educator and restricting the vision for the development of education;

- $\quad$ at the institutional level - the identified trend and the analyzed negative issues of its increase are a sure sign of a crisis in higher education.

These deficiencies appear to be strong demotivators for university lecturers and, in the context of the analyzed problems, destabilize the university. The 
underestimation of the seriousness of this fact hides the risk of gradually decreasing functions of the higher education institution as a key institution and marks a true danger of it becoming the first unstable unit that is a part of the "domino effect" in our education.

The indisputable cause-and-effect conditionality between motivation and activity reveals the importance of the problem about meaning-centered virtual fields, considered and acquired in the area of higher pedagogical education. For the unmotivated university lecturer it is impossible to develop the skills for proactively presenting the educational content to the audience of students - future educators. This teaching rigidity is identified as an obstacle in the context of quality education.

Therefore, this problem highlights the need for positive changes in the organization of the educational environment: to be effective, to provoke, support and encourage the individual development of the learner and to apply attractive forms of training.

\section{Application of a meaning-centered approach in the management of virtual educational environments in the university training of pedagogical staff}

Today's education system is undergoing a paradigm change that is a small-scale example of the changes in our society in terms of individual and social behaviors and relationships. The debates are held on the following strands:

1) education centered on the content/subject towards education centered on the learner/client/user;

2) education according to which knowledge and expertise are "here", and consumers are "there" towards an approach where the expertise of educational specialists is only a small part of the community expertise and consumers are both "here and there".

Knowing the potential of the personality and stimulating its expression at all code levels are the most important factors for developing the meaning-centered management of the virtual educational environment.

The meaning-oriented approach allows the identification of human, logistical and technological resources aimed at:

- promoting the development of effective thinking, action, relationships to achieve effective real achievements (Prensky, 2017);

- providing skills for complex problem solving, critical thinking, creativity, managing, coordinating with others, emotional intelligence, service orientation, cognitive flexibility, negotiation, judgment, and decision making, needed for the professions of the future .

The methodological platform for the validation of meaning-centered management of virtual educational environments are the theories of L. S. Vygotsky, K. Lewin, V. Frankl and S. Covey, adequate to the contemporary social requirements. 
The development of Slavic scientific thought, especially the work of the Russian psychologist L. S. Vygotsky represents the standpoint on "the creative intelligence", which could only be possible as a cognitive and emotional origin of human consciousness unity. All this we find in the ideas of Victor Frankl (Frankl, 2016).

On the other hand, the main thesis of constructivism is that a man is constructed in the social environment (L. S. Vygotsky). Knowledge originates and is formed by social interactions (sharing, comparison, debating) among subjects in the learning process. Through this dialogue, the social learning environment enables a person to specify their own meanings and help others to specify their own. In this way, mutual knowledge formation is achieved. This is a direct reflection of L. S. Vygotsky's sociocultural theory, which emphasizes the mentor's leadership and allows the learner to consistently master more complex levels of knowledge and understanding, thus gaining independent competence. The context (contextualism) becomes an integral part of the learning process: cultural and historical.

K. Lewin's field theory (Lewin, 1980) of active and passive adaptive tendencies in behavioral motivation reveals all conditions that are relevant to determine a behavior (characterizing both the current situation and the condition of the subject) and describes their dynamic relationships. The term "field" covers the factors of both the external (the environment) and the internal (subjective) situation (Lewin 1980).

Even in a cursory study, meaning-centered management as an approach strikingly differs from all theories, reducing behavior to personal dispositions and individual differences in them. Simple connections in the sense of an "irritantresponse" association are insufficient to explain the behavior. Its significance leads to the conclusion that sustainable development is not an impulsive response to thoughts and behavior, determined primarily by changing external circumstances or primary incentives, but it is the result of shared meaning in the subject-subjective interaction.

This is the reason why the meaning-centered management of virtual educational environments provides the conditions for maximum personalization of the learning process by transforming the traditional transmission process of educational communication into an organic and authentic dialogue.

The meaning-centered approach is based on the philosophy of Victor Frankl. In the 1980s, Stephen Covey affirmed this approach, convinced that the basis of subjective activity is the realization of one's own values. Innovative ideas and practical solutions to change the education systems that Ken Robinson, Lou Aronica, Malala Yousafzai, Tony Wagner, Passy Salberg, and others defend are also present. They are concentrated around the idea that "education does not have its own constant "utopia", it is an expression of the constant pursuit of creating the best conditions of learning for real people living in real communities in the real and changing world" (Robinson, Aronica, 2017). 


\section{Characteristics of the meaning-centered management of virtual educational environments}

The introduction of meaning-centered distance learning management reveals the role of the effective leader in education, which introduces innovations related to:

- enhanced control over knowledge, ideas and practices that form the given field of knowledge;

- a deep understanding of the traditions and achievements on which this knowledge is built.

In the conditions of virtual pedagogical communication, the meaningcentered approach allows the teacher to create environment that engages, provides opportunities, expects achievement and empowers trainees through:

- "inspiration: With their passion, they kindle their interest in the subject and inspire them to achieve the best;

- confidence: a help to acquiring skills and habits to convince them that they will also be able to develop their expertise cognition;

- creativity: they give the opportunity to experiment, explore, ask questions and develop skills and attitudes for original thinking” (Robinson, Aronica, 2017).

The above-mentioned professional pedagogical reflexes are feasible in compliance with the basic principle of meaning-centered approach, related to guaranteeing students' maximum freedom of choice. The result is a "pedagogical interaction for which the dynamic, the active, the surviving, the actively transforming moment for essential characteristics" (Prensky, 2017).

\section{Educational potential of the meaning-centered approach in the online environment}

The application of meaning-centered management of the virtual educational environment in higher pedagogical education ensures effective academic training of future teachers, uniting the following three projections:

1) In the conceptual aspect (What is the point?) - Reflects the importance and value of the disciplines (subject areas included in the curriculum of the respective educational qualification degree) in the context of the emerging role of education to develop humanity.

2) Personally (What will be developed?) - Reflects the range of key competences that students - future teachers should instill in adolescents in their training as a preparation for life.

The personal aspect actually sets the role of the proactive lecturer as a reference model in organizing a development-oriented pedagogical interaction (Robinson, Aronica, 2017) of:

- curiosity - the ability to ask questions and explore how the world works;

- creativity - the ability to create new ideas and to apply them in practice; 
- critical thinking - the ability to select and analyze information and ideas through argumentation and assessment;

- communication - the ability to clarify and ascertain the expression of thoughts and feelings through a variety of media tools and forms;

- collaboration - the ability to constructively cooperate with others;

- commitment - empathy and responsiveness;

- $\quad$ peace of mind - the ability to constantly connect with the inner world of feelings and develop a sense of personal harmony and balance;

- $\quad$ civic participation - the ability to participate constructively in the society and in the processes that make it sustainable.

3) In the active aspect (How will it be formed?) - reflects the activities, methods, forms, techniques, and components that structure the pedagogical interaction on the basis of cooperative learning: positive interdependence, face-to-face interaction, individual responsibility, and group analysis.

The authentic participation of students - future teachers - in such organized distance learning presupposes sustainable multiplication of the meaning-centered approach in their future professional and pedagogical realization.

\section{Conclusion}

The presented meaning-centered educational paradigm marks the effectiveness of distance learning by combining innovative solutions for higher pedagogical education in terms of organizing and conducting a learning process, reforming:

- the form of pedagogical communication: from monologic to dialogical;

- the choice of educational technology: from influence to interaction;

- the role of personal factors: from unification to pluralism, within pedagogical autonomy;

- the model of pedagogical thinking: from a reproduction of truth to selfseeking, transformation, creation of a new creative product.

\section{References}

Dermendjieva, S., G. Dyankova (2018). Proactive environment in the university pedagogic education (Theoretical Quality Framework for Higher Education Services). International Journal Knowledge, 23(1), 39-45. Social sciences. Institute of Knowledge Management - Skopje. Macedonia.

Frankl, V. (2016). Chovekyt v tyrsene na smisyl, Izdatelska kyshta „Hermes”: Sofiia.

Lewin, K. (1980). Topologiia i teoriia polia. Hrestomatiia po istorii psihologii, red. P. Ia. Galsperin, A. N. Zhdan, Moskva: MGU.

Prenski, M. (2017). Tryabva da provokirame detzata da iskat da promenyat sveta. Vestnik Kapital, KObrazovanie https://www.capital.bg/specialni_izdaniia/obrazovanie/2017/05/15/2961906_ mark_prenski_triabva_da_provokirame_decata_da_iskat_da/ 
Robinson, K. \& Aronika L. (2017). Kreativnite uchilishta - revoliuciiata, koiato preobraziava obrazovanieto. - RAABE-Bylgariia OOD.

Тодоров С. (2017). Марк Пренски: Трябва да провокираме децата да искат да променят света, Капитал, On-line magazine, published on 15. 05. 2017., retrieved from: https://www.capital.bg/specialni_izdaniia/obrazovanie/2017/05/15/2961906_ mark_prenski_triabva_da_provokirame_decata_da_iskat_da/

\title{
УСМЕРЕНО УПРАВЉАЊЕ ВИРТУЕЛНИМ ОБРАЗОВНИМ ОКРУЖЕНЕМ У АКАДЕМСКОЈ ОБУЦИ ПЕДАГОШКИХ СТРУЧЫАКА
}

\author{
Софиа Дерменђиева
}

Југозападни универзитет Неофит Рилски, Благоевград,Бугарска

\author{
Лазар Стошић \\ Институт за менаџмент и образовање,Регионални координатор за Србију, \\ Скопље, Македониа
}

\section{Гергана Дианкова}

Југозападни универзитет Неофит Рилски, Благоевград,Бугарска

У последњој институцији на крају образовног система, универзитет је посвећен припреми компетентних стручњака за сваку професионалну област, укључујући будуће наставнике. Суштински циљ обуке педагошких стручњака јесте упознавање потенцијала личности и подстицање њеног испољавања на свим кључним нивоима. Ситуација са Covid-19 указала је на његов све већи значај, с обзиром на хитну потребу да се пређе са лицем у лице ка учењу на даљину. Током епидемије која се брзо ширила, улога ИКТ-а у образовању постала је јасна. Доказано је да у условима глобалне кризе информационе и комуникационе технологије успешно посредују у процесу учења. Утврђено је да су дигиталне компетенције кључне за субјекте у педагошкој интеракцији, јер омогућују дијалог у виртуалном образовном окружењу. Несумњиво, основа његове квалитативне примене утиче на мотивацију за самоактуализацију интеракције између наставника и ученика. Како је уочена потреба за побољшањем квалитета образовања на даљину, у овом чланку су представљене предности управљања виртуелним образовним окружењем у фокусу на значењу у академској припреми педагошких специјалиста. Следећа питања постају релевантна: (1) У чему је значење?; (2) Шта ће се развијати?; (3) Како ће се формирати?, што сачињава концептуални, лични и делатни аспект педагошке интеракције из даљине.

Кључне речи: високо педагошко образовање, усмерено управљање у виртуелном окружењу, квалитет образовања на даљину, професионално-педагошка компетенција.

Citiranje članaka: Dermendjieva, S., Stošić, L. i Dyankova G. (2020). Meaningcenetered management of the virtual educational environment in the academic training of pedagogical specialists. Godišnjak za pedagogiju, 5(1), 73-80. 